\title{
Effects of the activated sludge performance in the sequencing batch reactor
}

\author{
Huiting Zhang ${ }^{1,}$, , Zixuan Zhong ${ }^{1, b}$, Feng Luo ${ }^{1,{ }^{*}}$ \\ ${ }^{1}$ Research Center of Bioenergy \& Bioremediation, Southwest University, Chongqing, China. \\ ahuiting45@126.com, \\ b1533729046@qq.com. \\ *van77@swu.edu.cn
}

Keywords: SBR, settleability, DO, light, cycles

Abstract. To explore the factors affecting sludge settlement, cultivation of aerobic activated sludge in a 20L sequencing batch reactors (SBR), using sludge in the aeration pool of the sewage plant as seed sludge, keep in room temperature $\left(20^{\circ} \mathrm{C} \sim 22^{\circ} \mathrm{C}\right)$, artificial synthetic wastewater. By changing the SRT, DO, running cycles and lighting condition, monitoring sludge settlement ratio (SV), mixed liquor suspended solids (MLSS) and the sludge volume index (SVI).

The novel results we found were that without light, the sludge were prone to inflation easily. Meanwhile, filamentous bacteria could be easily inflated under low DO; running cycles have an effect on sludge settle ability, three cycles a day had much lower SVI value than once a day. When the DO stay from $2 \mathrm{mg} / \mathrm{L}$ to $6 \mathrm{mg} / \mathrm{L}$, one cycle a day, the sludge performance can keep stable, ammonium-nitrogen removal rate can reach more than $70 \%$.

\section{Introduction}

Control of wastewater pollution is the most important part of environmental construction. Activated sludge treatment with its high efficient removal of organic pollutants from sewage, had become the core subject of biological treatment on wastewater. While the performance of sludge settlement directly affect the treatment effect of wastewater[1]. Currently, studies related to the factors of activated sludge settlement mainly on temperature, dissolved oxygen, sludge load, sludge age and $\mathrm{pH}[2]$, but rarely on the effect of light. In our study, Based on the SBR reactor with total volume 20L, at room temperature $\left(20{ }^{\circ} \mathrm{C} \sim 22{ }^{\circ} \mathrm{C}\right)$, synthetic wastewater, focused on the factors of light, running cycles and dissolved oxygen which had effect on sludge sedimentation performance.

\section{Materials and methods}

\section{Reactor setup and operation}

A lab-scale aerobic SBR with a working volume of $15 \mathrm{~L}$ was used under treatments. A pump was used to supply influent oxygen into the reactor. The running cycles during different phases are shown in Table 1 . The reactor was operated at room temperature $\left(22^{\circ} \mathrm{C}-25^{\circ} \mathrm{C}\right)$.

The seed sludge was got from the aeration pool of sewage plant in our city. The composition of primary synthetic wastewater was as follows: Glucose $500 \mathrm{mg} / \mathrm{L}, \mathrm{NH}_{4} \mathrm{Cl} 120 \mathrm{mg} / \mathrm{L}, \mathrm{NaHCO}_{3} 500 \mathrm{mg} / \mathrm{L}$, $\mathrm{KH}_{2} \mathrm{PO}_{4} 11 \mathrm{mg} / \mathrm{L}, \mathrm{MgSO}_{4} 50 \mathrm{mg} / \mathrm{L}, \mathrm{CaCl}_{2}, 10 \mathrm{mg} / \mathrm{L}$.

\section{Analytical methods}

\section{Water quality analysis}

Measuring the BOD, ammonia nitrogen $\left(\mathrm{NH}_{4}{ }^{+}-\mathrm{N}\right)$, nitrite nitrogen $\left(\mathrm{NO}_{2}{ }^{-}-\mathrm{N}\right)$ and nitrate nitrogen $\left(\mathrm{NO}_{3}{ }^{-} \mathrm{N}\right.$ ) sludge settlement ratio (SV), mixed liquor suspended solids (MLSS), dissolved oxygen (DO) everyday, collected and analyzed the results of all data, adjusted for the following step of the experiments. Specific measurement methods are shown in Table1. 


\begin{tabular}{llll}
\hline Content & Methods & Content & \multicolumn{1}{c}{ Methods } \\
\hline BOD & dilution inocula method & SV & 30min \\
$\mathrm{NO}_{2}^{-}-\mathrm{N}$ & N-(1-naphthyl)-ethylenediamine & MLSS & gravimetric method \\
$\mathrm{NO}_{3}^{-}-\mathrm{N}$ & ultraviolet & DO & Iodometric method \\
$\mathrm{NH}_{4}{ }^{-}-\mathrm{N}$ & nessler's reagent & phenotype & microscopy \\
\hline
\end{tabular}

\section{Operation conditions of the SBR}

The system kept running for $73 \mathrm{~d}$. We adjusted some parameters to fit the changeable results Table 2 .

Table 2. The operating parameters for SBR system.

\begin{tabular}{|c|c|c|c|c|c|c|c|c|}
\hline $\begin{array}{l}\text { Operationa } \\
1 \text { day }(d)\end{array}$ & $\begin{array}{l}\text { Cycle } \\
\text { (h) }\end{array}$ & $\begin{array}{l}\text { Running cycle } \\
\text { (time/d) }\end{array}$ & $\begin{array}{l}\text { aeration } \\
\text { rate }\left(\mathrm{m}^{3} / \mathrm{h}\right)\end{array}$ & $\begin{array}{l}\text { Loading Rate } \\
(\mathrm{kgCOD} /(\mathrm{kgMLSS} \cdot \mathrm{d}) \\
\quad)\end{array}$ & $\begin{array}{l}\text { Aerobic } \\
\text { stage } \\
\\
\qquad \\
\\
\\
\text { h } \\
(\end{array}$ & $\begin{array}{l}\text { Anoxic } \\
\text { Stage (h) }\end{array}$ & $\begin{array}{l}\text { Settling } \\
\text { (h) }\end{array}$ & $\begin{array}{l}\text { Effluent } \\
\text { withdrawal }\end{array}$ \\
\hline $1 \sim 34$ & 9.5 & 1 & 0.14 & 0.482 & 8 & 0.1 & 1 & 0.15 \\
\hline $35 \sim 43$ & 9.5 & 1 & 0.1 & 0.319 & 8 & 0.1 & 1 & 0.15 \\
\hline $44 \sim 46$ & 7.5 & 3 & 0.1 & 0.271 & 7 & 0.1 & 0.5 & 0.1 \\
\hline $47 \sim 73$ & 9.5 & 2 & 0.05 & 0.271 & 8 & 0.1 & 1 & 0.15 \\
\hline
\end{tabular}

\section{Results and discussion}

\section{Effect of DO on the sludge settling performance}

\section{Effect of aerobic sludge on settle ability}

As shown in the Fig 1, with the change of dissolved oxygen, SVI values keep stable within a certain range, the sludge had a well settlement performance, Epistylisurceolata appeared (Fig 2a)

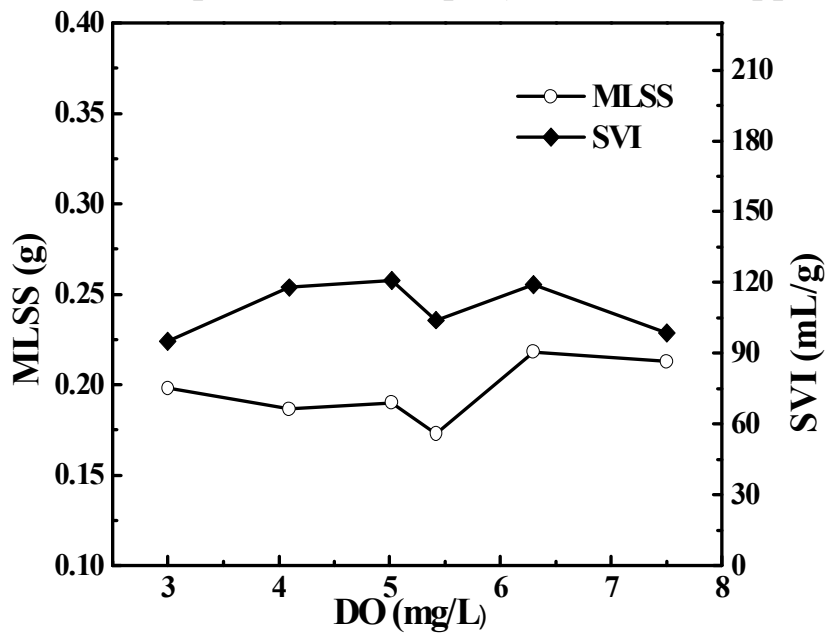

Fig. 1 The reaction of aerobic activated sludge settlement on efficient DO.

When the dissolved oxygen got over than $2 \mathrm{mg} / \mathrm{L}$, sludge sedimentation performance kept well. there was not any sludge bulking phenomenon. The sludge bulking caused by excessive the growth of filamentous bacteria. SBR system can effectively inhibit the occurrence of this phenomenon, the main reason is that for the larger aeration in SBR system, the aeration intensity in wastewater is enough to support a high level of DO [3] which created suitable conditions for the formation of aerobic granular sludge[4]. There will be increasingly rich of microbial phase gathered, such as the protozoan and metazoan attach to the surface of sludge. Rich microbial phase have good influence on in the wastewater pollutants removal. When the treatments go well, there will be not only the bacteria but also protozoan and metazoan.

Through the microscope, we observed that there some epistylis on the surface of sludge. Microbes in sludge can be divided into filamentous bacteria (aerobic bacteria) and rubber mission bacteria (facultative anaerobe), through control SBR equipment within anaerobic and aerobic oxygen alternating, total biomass of filamentous bacteria can be restricted that avoid sludge bulking[5]. 

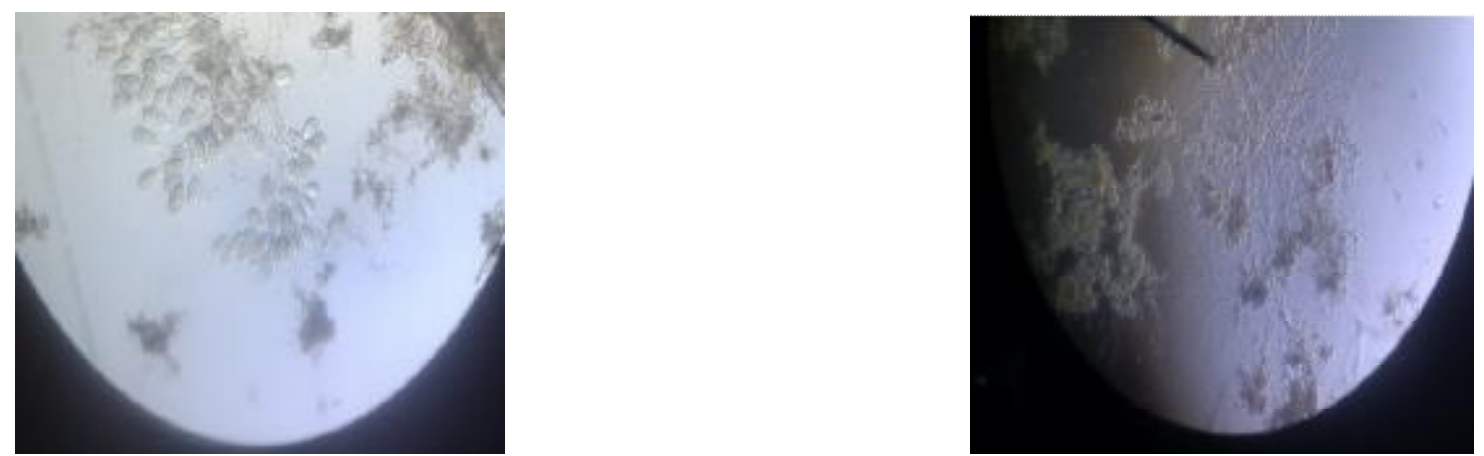

Fig 2a. Microscope observation in aerobic condition. b. Observation in anaerobic condition.

\section{Effect of anaerobic sludge on settle ability}

When the DO stayed from $0.1 \mathrm{mg} / \mathrm{L}$ to $0.4 \mathrm{mg} / \mathrm{L}, \mathrm{SVI}$ increased above $150 \mathrm{~mL} / \mathrm{g}$ (Fig. 3). There were large amount filamentous bacteria appeared (Fig. 2b).

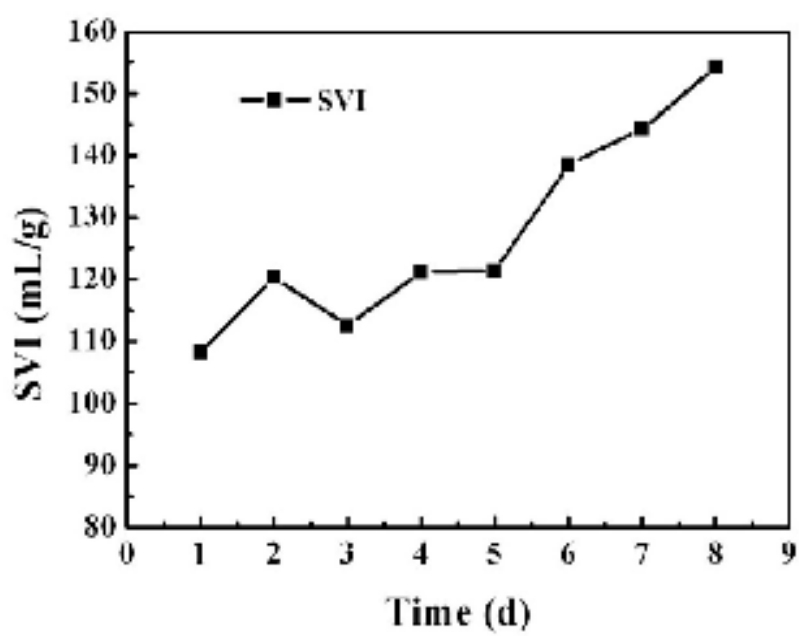

Fig. 3 SVI boost in low level of DO

The parameters as follows: SRT was $15 \mathrm{~d}$, running once for one day, Ns was $0.32 \mathrm{~kg} /(\mathrm{kg}$ MLSS $\cdot \mathrm{d})$. In this case, DO sludge bulked, caused by too low dissolved oxygen.

Generally, most aerobic bacteria cannot keep growing in too low dissolved oxygen conditions. Although filamentous bacteria are aerobiotic, they have long hyphae, they own larger surface area than other aerobic bacteria in zoogloea, so that they gain dissolved oxygen easily to keep rapid growth, in such a low oxygen environment, resulting in bulking[6].

On the other hand, the power of the hydraulic shear force is determined by the velocity of gas migration from the downside of the reaction and the aeration rates is the primary important factor to the hydraulic shear force[7]. In high level velocity of gas migration, the redundant filamentous bacteria are prone to fall off from the surface of sludge, while under low level of gas velocity, they cannot be separated by the hydraulic shear force.

\section{Effect of cycles on sludge settlement}

With different running cycles in one day, nutrients in sludge changed, SVI showed unsimiliar trends with different running cycles. We ran the system once a day, twice a day and three cycles a day, and detected SVI to identify the change with different running conditons (Fig. 4). 


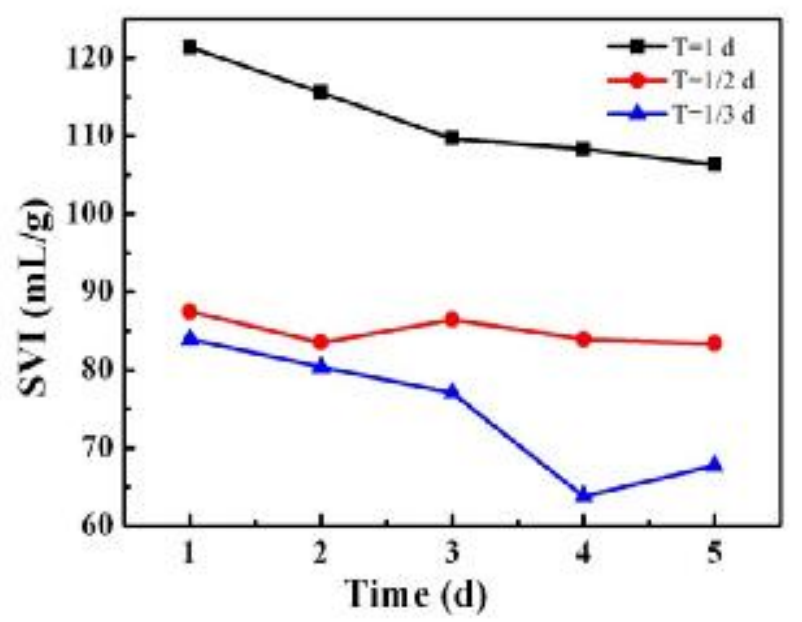

Fig. 4 Comparison of SVI in different running cycles.

It showed that running for once a day had higher SVI value than three cycles a day, the less cycle times it run, the higher SVI it would be.

Short cycle running can promote a sludge granulation, but if running cycle too frequently, it would lead to excessive loss of microorganisms which is not conducive to the formation of aerobic granular sludge [8]. So the SVI of three cycles a day was lower than once a day. When other conditions being stable, adding running cycles for one day, more nutrition supplied to the sludge, with the increase of organic, heterotrophic bacteria proliferated. The required carbon sources and nitrogen sources added, and supplied the adequate aeration, sludge would be fast-growing, which lead higher MLSS, finally, SVI reduced.

\section{Effect of light on sludge settling}

Under the same conditions, without shading, sludge sedimentation showed good performance, when the reactor was covered with a newspaper, SVI increased promptly, finally lead to the sludge bulking (Fig. 5).

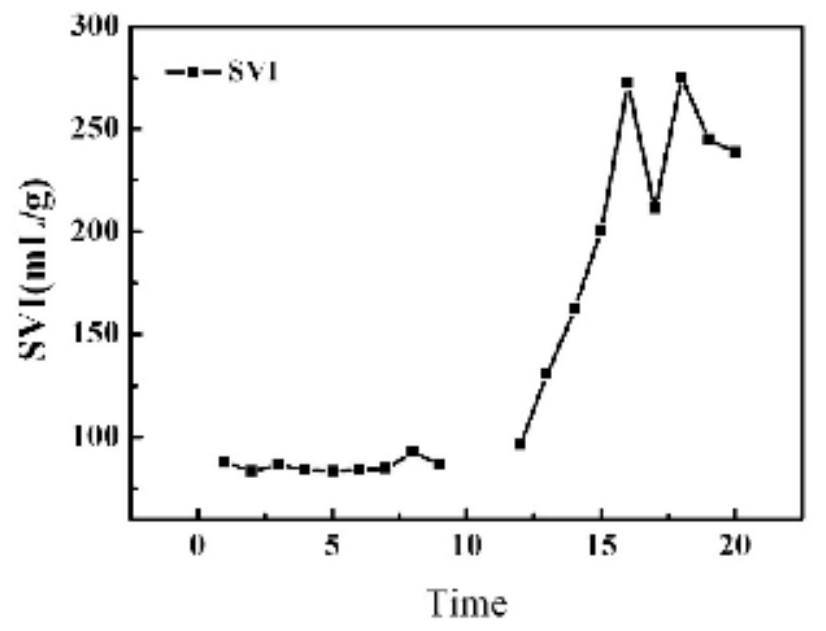

Fig 5. Sludge settle performance with shading and without shading

As is shown in the figure, the operating parameters are as follows: two cycles one day, aeration rate was $0.05 \mathrm{~m}^{3} / \mathrm{h}$, sludge density Ns was $0.27 \mathrm{~kg} /(\mathrm{kg}$ MLSS $\cdot \mathrm{d})$. From the former 9 days without shading, SVI kept stable without large fluctuations, from 10th day, coved the reaction with paper, SVI straightly climbed, till the last, SVI got as high as 250, sludge bulking occured.

Compared with the reaction with to without the light, obvious phenomenon could be found. light has an effect on sludge sedimentation performance. Light have a good effect on microbes in the sludge, bacterial diversity may be changed by the darkness, that lead to the sludge settlement performance. 


\section{Conclusions.}

Based on the cultivation of aerobic activated sludge in a 20L sequencing batch reactors (SBR). We changed several operation parameters including SRT, DO, running cycles and lighting condition, monitored SV, MLSS, SVI of the sludge, finally, we got the novel results related to the effects of sludge settleability in SBR.

1. Light have an effect on sludge sedimentation, without light, the sludge are prone to inflation easily, the microflora structure related to this results needed to be further explored;

2. Running cycles have an effect on sludge settleability, three cycles a day had better effect on sludge settleability than once a day.

3. Filamentous bacteria have more advantages than other aerobic bacteria in low dissolved oxygen, it is prone to sludge bulking and less filamentous bacteria is conducive to improve settleability[9].

With the stable results above, further exploration such as molecular methods, bacteria diversity analysis can be done in the future work.

\section{Acknowledgements}

This work was financed by Fundamental Research Funds for the Central Universities (Grant No: XDjk2011B009) to Feng Luo, and Research Funds of Scientific Platform and Base Construction (Grant No: cstc2014pt-sy0017) to Feng Luo. The Recruitment Program for Foreign Experts (WQ20125500073). Chongqing Research Program of Social undertaking and Livelihood security (cstc2016shmszx1176).

\section{References:}

[1] Y. Sato, M. Nagasaka, G.J. Ding, Effect of Agitation on the Treatment Performance and Sludge Settleability in a SBR Process for Accelerated Nitrification., Japanese Journal of Water Treatment Biology 38 (2002) 175-182.

[2] A. Ekster, R. Sung, FORECASTING ENERGY SAVINGS ACHIEVED BY AUTOMATION OF DISSOLVED OXYGEN AND SLUDGE AGE CONTROLS AND OPTIMIZATION OF SET POINTS, Proceedings of the Water Environment Federation (2007) 6251-6261.

[3] C. Zhu, Z. Wang, P. Wang, X. Mei, A comparative study on the performance of single- and double-deck MBRS under same aeration intensities for wastewater treatment, Fresenius

Environmental Bulletin 21 (2012) 1841-1847.

[4] J.H. Tay, Q.S. Liu, Y. Liu, The effects of shear force on the formation, structure and metabolism of aerobic granules., Applied Microbiology and Biotechnology 57 (2001) 227-233.

[5] M. Tang, S. Zhang, Q. Tian, Filamentous Bacteria and Filamentous Bulking Sludge, Guangdong Chemical Industry (2014).

[6] T.M. Williams, R.F. Unz, Isolation and characterization of filamentous bacteria present in bulking activated sludge, Applied Microbiology and Biotechnology 22 (1985) 273-282.

[7] S. Kucukali, S. Cokgor, Energy Concept for Predicting Hydraulic Jump Aeration Efficiency, Journal of Environmental Engineering 135 (2009) 105-107.

[8] Sheng Zhang, Jing Li, Hui Yuan, Xiaohao Jiang. The Impact of Factors on Formation and Performance of Aerobic Granular Sludge. SCIENCE \& TECHNOLOGY INFORMATION.1 (2009) 150. In Chinese.

[9] Jingfeng Wang, Xuan Wang, Min Ji, Shan Lu, Weihua Liu, Zaoyan Yang. Sludge Characteristics in an Aerobic Granular Sludge Membrane Bioreactor. ENVIRONMENTALSCIENCE. 28 (2007) 1034-1038. In Chinese. 